still associated after the effects of heart rate had been taken into account.

We cannot explain our finding satisfactorily, but through the investigation of children we have been able to exclude explanations which have relevance only to adults. If our findings are not simply an artefact of the examination procedure, then they suggest that in the more developed countries the relations seen in adults between four risk factors for CHD-blood pressure, adiposity, blood sugar, and serum cholesterol-are already evident in childhood.

We thank Professor A C Arntzenius and Professor J H de Haas for their help and encouragement in organising and carrying out this study; Dr B Grab of the World Health Organisation headquarters, Geneva, for providing the data tape; and $\mathrm{Mr}$ A Sadler for making the insulin determinations. We also thank Professor R M Acheson and Professor F H Epstein for their helpful comments on the manuscript. The Netherlands Heart Foundation provided financial support for the survey.

\section{References}

Epstein, F H, Circulation, 1967, 36, 609.

Florey, C du V, MD thesis, Cambridge, 1974

Epstein, F H, paper given at VIth World Congress of Cardiology, 1970.

4 Florey, C du V, and Acheson, R M, Vital Health Statitics, series II, No 34. Washington DC, US Government Printing Office, 1969.

${ }^{5}$ Stamler, J, et al, Bulletin of the New York Academy of Medicine, 1969, 45, 1306.

6 Stamler, J, et al, Circulation, 1974, 50, suppl 3, p 147.

7 Jarrett, J, and Keen, H, Complications of Diabetes, chap 5. London, Arnold, 1975.

${ }^{8}$ Uppal, S, MD thesis, Leiden, 1974.

9 Florey, C du V, Lowy, C, and Uppal, S, submitted for publication.

${ }^{10}$ Long, M, Dunlop, J R, and Holland, W W, Archives of Disease in Childhood, 1971, 46, 636.

${ }^{11}$ Hoffman, W S, fournal of Biological Chemistry, 1937, 120, 51.

12 Huang, T C, et al, Analytical Chemistry, 1961, 33, 1405.

${ }^{13}$ Morgan, C R, and Lazerow, A, Diabetes, 1963, 12, 115.

${ }^{14}$ Draper, N, and Smith, H, Appiied Regression Analysis. London, Wiley, 1966.

15 Lauer, R M, et al, Circulation, 1974, 50, Suppl 3, p 124

\title{
Growth, behaviour, and educational achievement of Jamaican children with sickle-cell trait
}

\author{
M T ASHCROFT, PATRICIA DESAI, S A RICHARDSON, G R SERJEANT
}

British Medical fournal, 1976, 1, 1371-1373

\section{Summary}

A longitudinal study of the mental and physical development of 200 children with normal haemoglobin and 21 with the sickle-cell trait was carried out in a small rural community in Jamaica. At about 2 and 10 years of age heights and weights showed no significant differences. At about 10 years of age classroom behaviour, sociability, and educational achievement were similar. The results suggest that the sickle-cell trait does not affect growth and mental development.

\section{Introduction}

In homozygous sickle-cell disease some $80-97 \%$ of the total haemoglobin is sickle haemoglobin ( $\mathrm{Hb} \mathrm{S}$ ), and these high levels are associated with well recognised pathophysiological sequelae. Heterozygous sickle-cell trait, however, is characterised by about $20-50 \% \mathrm{Hb} \mathrm{S}$ and is essentially benign, though in this disease generalised or localised anoxia may occasionally produce conditions such as splenic infarction ${ }^{1}$ or haematuria. ${ }^{2}$ Vascular occlusive episodes have also been attributed to the sickle-cell trait but the causal role of $\mathrm{Hb} \mathrm{S}$ has not been confirmed. ${ }^{3}$

A report from the USA ${ }^{4}$ suggested that some aspects of the physical and mental development of children with the sickle-cell

\footnotetext{
Medical Research Council Laboratories (Jamaica), University of the West Indies, Kingston 7, Jamaica WI

M T ASHCROFT, DSC, MRCP, epidemiologist

PATRICIA DESAI, BA, statistician

G R SERJEANT, MD, MRCP, director
}

Department of Paediatrics, Albert Einstein College of Medicine, Yeshiva University, Bronx, New York

S A RICHARDSON, PHD, professor of paediatrics and community health trait may be impaired. In view of the far-reaching implications we have compared the growth, behaviour, and educational achievement of Jamaican children with the trait and with normal haemoglobin.

\section{Subjects and methods}

All the children had been included in early childhood studies of growth and development in Lawrence Tavern, a rural area of Jamaica. ${ }^{5} 6$ The geographically defined district is about $30 \mathrm{sq} \mathrm{km}$ and has a total population of 8000 , mainly of African origin. The predominant occupation is subsistence farming, and the people are, in general, poor, although few are destitute. The pattern of disease is like that of a temperate rather than tropical country. Parasitic infections such as malaria, schistosomiasis, and filariasis are absent, although intestinal helminthiasis is common. Mortality rates in the first two years of life are high but subsequently fall to about the same as in the United Kingdom.

In 1974,247 children aged $9-11 \frac{1}{2}$ years who were still living in the area were available for further investigations. A test of reading, spelling, and arithmetic (the Wide Range Achievement Test) ${ }^{7}$ was given to each child individually. The children, with the exception of four who were not enrolled at any school, were pupils at nine local schools. Teachers and fieldworkers completed questionnaires, from which indices of classroom behaviour and sociability were derived. School attendance was obtained for the previous two terms from school registers. Medical histories were taken and clinical examinations performed if deemed necessary. Socioeconomic status, based on housing, furnishing, income, and employment, was assessed on a four-point scale after a home visit by a field worker. Family structure, which may also influence educational achievement and behaviour, was recorded. Heights and weights at about 2 years of age were obtained from the children's records and were measured again in 1974. Each measurement was expressed as a standard score, which is the number of standard deviations by which the measurement differs from the mean of a reference population of the same age and $\operatorname{sex}^{5}{ }^{8}$

In 1975 venous blood was obtained from 231 (94\%) of the 247 children and examined by haemoglobin electrophoresis on cellulose acetate and agar gel. The presence of $\mathrm{Hb} \mathrm{S}$ was confirmed by metabisulphite sickle tests. The study was "double blind," since genotypes were determined by staff unaware of the results of other assessments. 


\section{Results}

Electrophoresis showed normal haemoglobin in 200 children (genotype AA) and the sickle-cell trait in 21 (genotype AS), subsequent analysis being confined to these two groups. The genotypes of the other 10 children were AC (6), SC (1), and rarer variants (3).

The health of the children was, in general, good. Twenty-four had had admissions to hospital, mainly for trauma (six), minor surgery (six), and infections (four). No differences were apparent in the prevalence or pattern of hospital admissions between children with the AA and AS genotypes. Four children, all with AA genotype, had chronic incapacities (severe mental retardation, epilepsy, Hirsch- sprung's disease, and congenital leg deformity). Mean haemoglobin levels measured in 1975 showed no significant difference with sex or genotype, the mean level in children with the AA genotype being $12.1 \pm \mathrm{SD} 0.9 \mathrm{~g} / \mathrm{dl}$ and in those with the AS genotype $12.3 \pm$ $0.7 \mathrm{~g} / \mathrm{dl}$.

Table I shows that the AS and AA children were alike in age, ethnic origin, socioeconomic status, school attendance, and family structure, as assessed by the proportion living with both parents. The standard scores for height and weight at 2 and 10 years (table II) and assessments of educational achievement, school behaviour, and sociability (table III) showed no consistent trends or significant differences between the two groups.

TABLE I-Comparison of various factors that may influence growth, achievement, or behaviour among children with AA and AS genotypes

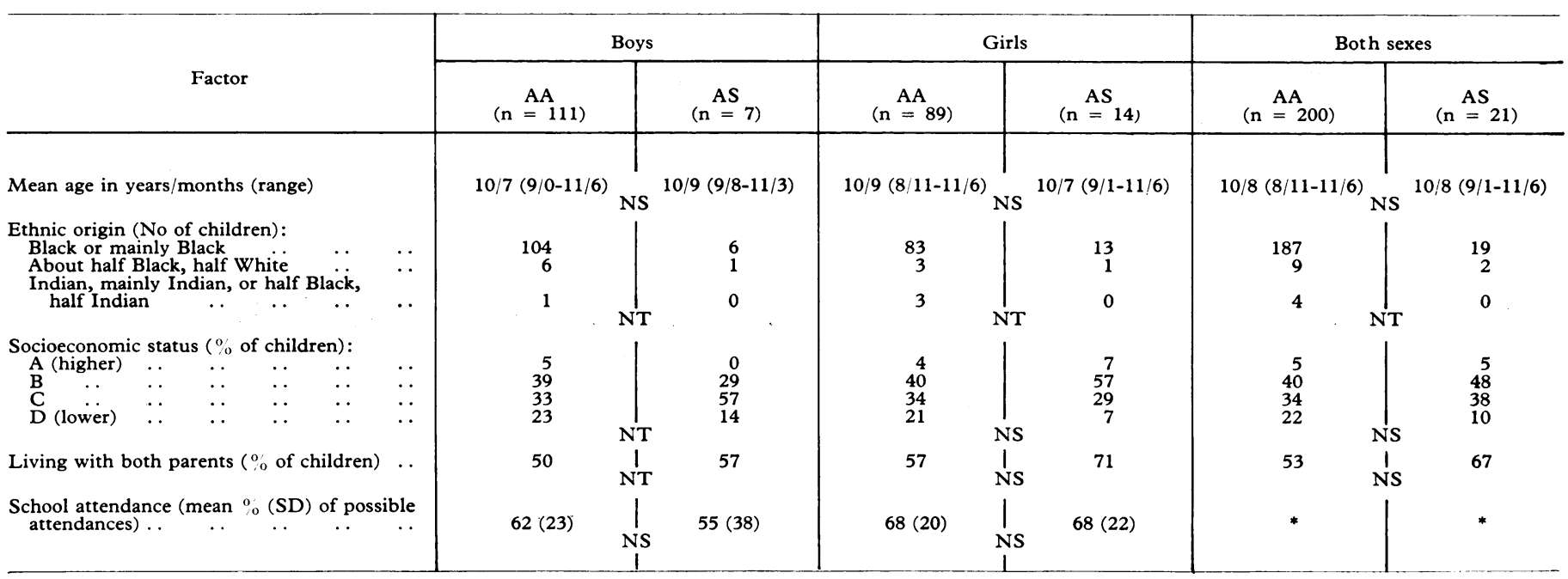

*Boys and girls not combined owing to overall differences between sexes.

NS $=$ No significant difference $\left(t\right.$ test, $x^{2}$ test, or Fisher's exact test $)$

TABLE II-Height and weight (standard scores*) at about 2 and 10 years of age of children with AA and AS genotypes

\begin{tabular}{|c|c|c|c|c|c|c|c|}
\hline \multirow{2}{*}{\multicolumn{2}{|c|}{ Growth measure }} & \multicolumn{2}{|c|}{ Boys } & \multicolumn{2}{|c|}{ Girls } & \multicolumn{2}{|c|}{ Both sexes } \\
\hline & & AA & AS & AA & AS & AA & As \\
\hline $\begin{array}{l}\text { Mean height } \\
\text { scores (SD) }\end{array}$ & $\left\{\begin{array}{l}\text { At } 2 \text { years } \\
\text { No of children } \\
\text { At } 10 \text { years } \\
\text { No of children }\end{array}\right.$ & $\begin{array}{c}-0.11(0.97) \\
111 \\
+0.25(0.97) \\
111\end{array}$ & $\begin{array}{c}-0.03(0.73) \\
7 \\
+0.46(0.73) \\
7\end{array}$ & $\begin{array}{c}-0.27(1.13) \\
88 \\
+0.34(1.00) \\
89\end{array}$ & $\begin{array}{c}-0.10(0.89) \\
14 \\
+0.41(0.80) \\
14\end{array}$ & $\begin{array}{c}-0.18(1.04) \\
199 \\
+0.29(0.99) \\
200\end{array}$ & $\begin{array}{c}-0.08(0.82) \\
21 \\
+0.43(0.76) \\
21\end{array}$ \\
\hline $\begin{array}{l}\text { Mean weight } \\
\text { scores (SD) }\end{array}$ & $\left\{\begin{array}{l}\text { At } 2 \text { years } \\
\text { No of children } \\
\text { At } 10 \text { years } \\
\text { No of children }\end{array}\right.$ & $\begin{array}{c}-0.01(1.01) \\
111 \\
+0.01(1.03) \\
\quad 111\end{array}$ & $\begin{array}{c}-0.04(1.21) \\
7 \\
-0.24(1.13) \\
7\end{array}$ & $\begin{array}{c}-0.07(0.94) \\
88 \\
0.00(0.99) \\
89\end{array}$ & $\begin{array}{c}-0.05(0.88) \\
14 \\
-0.06(0.60) \\
14\end{array}$ & $\begin{array}{c}-0.03(0.97) \\
199 \\
+0.01(1.01) \\
200\end{array}$ & $\begin{array}{c}-0.05(0.97) \\
21 \\
-0.12(0.79) \\
21\end{array}$ \\
\hline
\end{tabular}

*A standard score of 1.0 represents about $3.3 \mathrm{~cm}$ and $1.3 \mathrm{~kg}$ at 2 years and $6.9 \mathrm{~cm}$ and $4.7 \mathrm{~kg}$ at 10 years.

No significant differences were found between children with AA and AS genotypes ( $t$ test).

TABLE III-Indices of educational achievement, school behaviour, and sociability in children with $A A$ and $A S$ genotypes

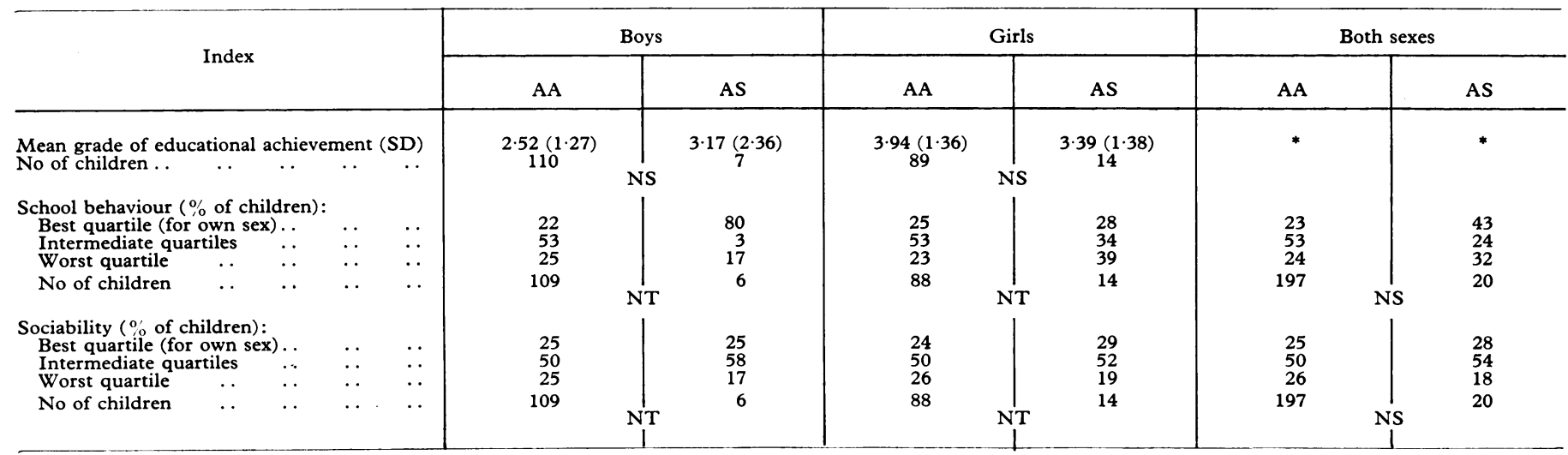

* Boys and girls not combined owing to overall differences between sexes. 


\section{Discussion}

Growth, behaviour, and educational achievement are influenced by many factors, and, although we found that the AA and AS children were alike in some of these, we cannot be certain that they were alike in all. Every child, however, had lived since early childhood in a small community in which living standards, child rearing practices, and educational opportunities varied within narrow ranges, and there were unlikely to be major differences in the backgrounds of the two groups.

The absence of differences in growth and achievement between children with the two genotypes conflicts with some of the results of the study in the USA, ${ }^{4}$ in which significantly lower weights and poorer performances in psychological-intellectual tests were found in 19 AS compared with 241 AA children aged 10-16 years. No evidence was presented in that report, however, to show that the two groups were matched for socioeconomic or other factors that might have influenced the measurements. Furthermore, the selection of patients from twin studies may complicate assessment of the results. Perinatal hypoxia is more likely to occur in twins, and, although levels of $\mathrm{Hb} \mathrm{S}$ are low in the sickle-cell trait at birth, the possible role of severe hypoxia precipitating sickling cannot be entirely excluded.
Both studies were limited by small numbers, and carefully controlled investigations of larger groups of children are needed. Meanwhile, the available evidence does not warrant the conclusion that che sickle-cell trait affects physical and mental development.

We thank Nurse Celia Barnes, Mr Alphonso Barnes, Mr Aston Chung, and Miss Karlene Mason for technical help, and the teachers, children, and families of Lawrence Tavern for their co-operation.

\section{References}

${ }^{1}$ Smith, E W, and Conley, C L, Bulletin of the Fohns Hopkins Hospital, $1955,96,35$.

${ }^{2}$ Allen, T D, fournal of Urology, 1964, 91, 177.

3 Serieant, G R, Clinical Features of Sickle Cell Disease, Amsterdam, North Holland Publishing Cornpany, 1974.

${ }^{4}$ McCormack, M K, et al, Pediatrics, 1975, 56, 1021

5 Standard, K L, Desai, P, and Miall, W E, Fournal of Biosocial Science, 1969, 1, 153.

${ }^{6}$ Desai, P, Standard, K L, and Miall, W E, Fournal of Biosocial Science, 1970, 2, 133.

7 Jastak, J, Wide Range Achievement Test. Delaware, Storey, 1946.

8 Ashcroft, M T, and Lovell, H G, Fournal of Tropical Pediatrics, 1966, 12, 37.

\title{
Comparison of intra-amniotic prostaglandin $\mathrm{F}_{2} \alpha$ and hypertonic saline for induction of second-trimester abortion
}

\author{
International multicentre study by the Task Force on the Use of Prostaglandins for the \\ Regulation of Fertility of the World Health Organisation's Expanded Programme on \\ Research, Development, and Research Training in Human Reproduction
}

British Medical fournal, 1976, 1, 1373-1376

\section{Summary}

The efficacy and safety of intra-amniotic prostaglandin (PG) $F_{2 \alpha}(25 \mathrm{mg}$ repeated in six hours) and hypertonic salline $(200 \mathrm{ml} \mathrm{20} \% \mathrm{NaCl})$ were compared in an international multicentre randomised study organised by the World Health Organisation's prostaglandin task force.

Clinical co-ordinators of the study were: M Bygdeman (Karolinska Hospital, Stockholm, RTC*); M P Embrey (John Radcliffe Hospital, Oxford); P Gillett (Montreal General Hospital, Montreal, CRC $\dagger$ ); R Wilson (Human Reproduction Unit, World Health Organisation, 1211 Geneva); and N Wiqvist (Karolinska Hospital, Stockholm, RTC).

Participating centres were: Edmonton University Hospital, Edmonton, Canada, CRC (Dr D Reid); Halifax University Hospital, Halifax, Canada, CRC (Dr C Tupper); Notre Dame Hospital, Montreal, CRC (Dr L Fortier); Jewish General Hospital, Montreal, CRC (Dr M M Gelfand); Montreal General Hospital, Montreal, CRC (Dr P Gillett); Saskatoon University Hospital, Saskatoon, CRC (Dr T B MacLachlan); Toronto General Hospital, Toronto, CRC (Dr J Gare); Toronto Western Hospital, Toronto, CRC (Dr W Paul); Vancouver General Hospital, Vancouver, CRC (Dr N Lee); Winnipeg General Hospital, Winnipeg, CRC (Dr A T Coopland); Institute for Research in Reproductive Biology, KEM Hospital, Bombay, CRC (Professor Purandare); Post Graduate Institute of Medical Education and Research, Chandigarh, India, CRC (Professor Devi); All India Institute of Medical Sciences, New Delhi, RTC (Professor Hingorani); Women's Hospital University of Southern California, Los Angeles, CRC (Dr Ballard); All Union Institute of Obstetrics and Gynaecology, Moscow, RTC (Professor Persianinov); Ginekolosko-Akuserska Klinika, Belgrade (Professor Husar); and Ginekolosko-Akuserska Bolnica, Belgrade (Dr Rajkavoc).

${ }^{*} \mathrm{RTC}=$ Collaborative centre for research and training in human reproduction.

$\dagger \mathrm{CRC}=$ Collaborative centre for clinical research on human reproduction .
Both hypertonic saline and $\mathrm{PGF}_{2 \alpha}$ were found to be effective in terminating second-trimester pregnancy. The main advantage of $\mathbf{P G F}_{2 \alpha}$, however, was its greater efficacy, with significantly higher success rates in the first 48 hours. Out of 717 women given PGF $_{2 \alpha} 614(85.6 \%)$ aborted within 48 hours; by 24 hours $439(61.2 \%)$ had aborted, and by 36 hours $574(80 \cdot 1 \%)$ had aborted. Out of 796 women given hypertonic saline $641(80 \cdot 5 \%)$ aborted within 48 hours; however, by 24 and 36 hours, respectively, only $161(20 \cdot 2 \%)$ and $462\left(58^{\circ}\right)$ had aborted.

Although $\mathbf{P G F}_{2 \alpha}$ was associated with a somewhat higher frequency of minor side effects than hypertonic saline, notably vomiting and diarrhoea, these were within acceptable limits. Only 59 women $(8.2 \%)$ in the prostaglandin group had more than four episodes of vomiting and $11\left(1.5^{\circ}\right)$ more than four episodes of diarrhoea. Other side effects occurred only occasionally. No difference was found between the two groups in the frequency of incomplete abortion or excessive bleeding.

\section{Introduction}

Early studies of the intra-amniotic administration of prostaglandin (PG) $F_{2 \alpha}$ showed that doses of $5-25 \mathrm{mg}$ often needed to be repeated to induce therapeutic abortion. ${ }^{1-8}$ When an initial dose of $25 \mathrm{mg}$ was repeated in 24 hours (if abortion was not imminent) a success rate of about $95 \%$ was achieved within 48 hours with an induction-abortion interval of about 30 hours. $^{4}{ }^{9-11}$ When the second injection was given after six hours the success rate was as high or higher and the induction-abortion interval fell to about 20 hours. ${ }^{1011}$

Since the half life of $\mathrm{PGF}_{2 \alpha}$ (25-40 mg injected) in amniotic fluid is $13-18$ hours, ${ }^{11-13}$ its concentration may fall too low for 